\title{
TRADE LIBERALIZATION AND LABOR SHARES IN CHINA
}

\author{
by
}

\author{
Fariha Kamal** \\ U.S. Census Bureau
}

Mary E. Lovely

Syracuse University

Devashish Mitra*
Syracuse University

CES 14-24 May, 2014

The research program of the Center for Economic Studies (CES) produces a wide range of economic analyses to improve the statistical programs of the U.S. Census Bureau. Many of these analyses take the form of CES research papers. The papers have not undergone the review accorded Census Bureau publications and no endorsement should be inferred. Any opinions and conclusions expressed herein are those of the author(s) and do not necessarily represent the views of the U.S. Census Bureau. All results have been reviewed to ensure that no confidential information is disclosed. Republication in whole or part must be cleared with the authors.

To obtain information about the series, see www.census.gov/ces or contact Fariha Kamal, Editor, Discussion Papers, U.S. Census Bureau, Center for Economic Studies 2K132B, 4600 Silver Hill Road, Washington, DC 20233, CES.Papers.List@census.gov. 


\begin{abstract}
We estimate the extent to which firms responded to tariff reductions associated with China's WTO entry by altering labor's share of value. Firm-level regressions indicate that firms in industries subject to tariff cuts raised labor's share relative to economy-wide trends, both through input choices and rent sharing. Labor's share of value is an estimated 12 percent higher in 2007 than it would be if tariffs had remained at their 1998 levels. There is significant variation across firms: the impact is larger where market access is better and it is influenced by union presence and state ownership.
\end{abstract}

\footnotetext{
${ }^{*}$ Corresponding Author; ${ }^{* *}$ Any opinions and conclusions expressed herein are those of the author and do not necessarily represent the views of the U.S. Census Bureau. The research in this paper does not use any confidential Census Bureau information.

The authors gratefully acknowledge comments from seminar participants at the 2013 ASSA meetings, fall 2013 Mid-West International Economics Meetings, Empirical Investigations in International Trade at the University of Virginia, the University of Toronto, the Center for Economic Studies at the U.S. Census Bureau, Shanghai Jiao Tong University, and George Washington University. We especially acknowledge comments by Loren Brandt, William McGuire, James Spletzer, Dennis Yang, and Xiaodong Zhu. We thank Xuepeng Liu for data on Chinese tariff rates and Siping Luo for firm remoteness measures.
} 


\section{Introduction}

China's economic reforms and rapid development have produced spectacular growth in both real incomes and income inequality. While real incomes grew by more than 10 percent per annum between 1998 and 2007, one measure of the distribution of income, labor's share of national income, fell from $50 \%$ to only $40 \% .^{1}$ Given the importance of international trade and investment to China's development, it is natural to seek explanations for the declining labor share in changing commercial policy. The most prominent change during this time period is China's accession to the WTO in 2001, and in this paper we investigate the relationship between the associated tariff cuts and changes in labor shares at the firm level. Specifically, we estimate the extent to which tariff cuts influenced firm-level labor shares relative to economy-wide trends. Using an extensive panel of manufacturing firms, we ask whether firms in industries with relatively deep tariff cuts experienced smaller or larger declines in labor shares relative to others.

\footnotetext{
${ }^{1}$ Income Growth rate from World Bank, Economic Indicators; labor shares from Qian and Zhu (2012). Bai and Qian (2010) calculate a drop of 12.5 points in China's labor share of national income using official data for 1995 to 2007 , but after adjusting for changes in accounting methods, they estimate a drop of 7.2 points.
} 
As noted by Brandt et al., (2012), changes in import tariffs affect firm behavior via two channels: through the local price and variety of imports that compete directly with locally manufactured goods and through the price and variety of intermediate inputs. These channels have complex and sometimes opposing influences on firms' factor intensity, productivity, and markup and, thus, the share of value accruing to labor. The net effect of these influences on labor shares is, ultimately, an empirical question and one that we address with a large panel of firms during a ten-year period of declining tariff rates.

Reforms surrounding China's 2001 WTO accession produced significant liberalization despite the fact that China was already integrated into global production networks. Protection of domestic firms remained strong in industries for which domestic supply was deemed "sufficient," state enterprises were dominant, or industrial policy or national security supported domestic expansion. Through its accession agreements, China committed to the reduction of both tariff and non-tariff barriers to imports of industrial goods, including those in many of the most protected industries. Tariff reductions were phased over a period of ten years but the bulk of reductions took place immediately on January 1, 2002. The average import-weighted tariff rate on manufactured goods was lowered from about $20 \%$ in 1998 to about $9 \%$ by 2007 . $^{2}$

Using China's Annual Survey of Industrial Production, we estimate the effect of these tariff cuts on manufacturing firms' labor shares relative to economy-wide trends. Our theoretical framework permits trade reform to affect labor's share both through changes in input choices and through changes in rents shared with workers. Regressions estimated with this large panel of firms provide evidence of a positive and statistically significant effect of tariff cuts on labor shares of output and, alternatively, labor shares of value added. The average labor share of value is an estimated 12 percent higher in 2007 than it would be if tariffs had remained at their 1998

\footnotetext{
${ }^{2}$ Average effective applied tariff rate calculated by authors from data source shown in Table 1 below.
} 
levels and economy-wide trends were unchanged. Thus, our findings are consistent with the view that workers share part of the productivity gains from China's WTO accession identified by Brandt et al. (2012).

A key feature of our empirical analysis is that we estimate the response of labor shares to tariff cuts at the firm level, operating through multiple channels of influence. Additionally, we calculate firm-level markups of price over cost, using the method proposed by De Loecker, Goldberg, Khandelwal, and Pavcnik (2012). We include these estimated markups as an additional regressor in labor share equations, testing whether tariff cuts operate directly through input choices as well as indirectly through changes to firm-level rents. As De Loecker et al. find in their analysis of Indian firms, estimated Chinese firm markups are positively correlated with output tariffs, but negatively correlated with input tariffs. Overall, our empirical results indicate that tariff cuts raise markups and that higher markups lead to higher labor shares, indicative of rent sharing at the firm level. Importantly, even after controlling for markups, we find that tariff cuts increase labor shares, indicating the empirical presence of the channel that works through input choices and labor productivity.

To enhance identification, we allow the effect of tariff reform to vary by firm location and we find that the positive impact of tariff reductions on labor share is stronger where access to global markets is better. Using information on which firms have a labor union present in the enterprise, we are also able to explore the role of a union in shaping the firm response to trade reforms. Regression results indicate that while lower output tariffs lead to a higher labor share, the magnitude of the effect is smaller when a union is present. Interestingly, we find a significant and positive relationship between firm markups and labor shares only in domestic private firms in which a union is present, suggesting that a collective voice for workers does influence the 
degree of rent sharing within the firm. In contrast, foreign-invested enterprises with a union present exhibit no significantly different rent sharing behavior than do those without a union present. Lastly, we test the hypothesis that changes in labor share are stronger for non-state firms than for state firms, and find no statistically significant difference between state firms and domestic private firms in the degree to which trade liberalization raises labor shares, but we do find a significantly larger response among foreign-invested enterprises.

Our analysis focuses on changes in labor shares rather than changes in absolute real wages. Since the 1980s many countries have experienced declines in labor shares, but not all have experienced declines in real wages. ${ }^{3}$ Indeed, over the period 1998 to 2007, real annual urban wages in China grew by 13.2\% (Yang, Chen, and Monarch; 2012). Bentolila and SaintPaul (2003) describe a similar outcome for France during the period 1970-1990, when France experienced a sharp decline in the labor share yet a large increase in the average real wage. Labor's share of income is of interest in its own right, as Atkinson (2009) has pointed out, because a decline in labor share is associated with an increase in overall inequality even in the context of real wage growth. Further, Atkinson notes that changes in labor's share of income provide information on the extent to which workers benefit from higher productivity and is, thus, associated with social justice and fairness.

The results of this paper are related to a small cross-country literature examining the relationship between trade and labor's share of national income. A key contribution to this literature is Harrison (2005), who uses a panel of over a hundred countries for the period 19602000 to examine the impact of trade on labor share. She finds that an increase in globalization, as reflected in an increase in the share of trade in national income and a loosening of capital

\footnotetext{
${ }^{3}$ A recent International Labor Organization report (ILO, 2013) confirms that since the 1980s a majority of countries have experienced falling labor shares and finds that this has happened most frequently where wages have stagnated but also in some countries, such as China, where real wages have grown strongly.
} 
controls, is associated with a decline in labor's share in national income. A similar conclusion is reached by Guscina (2006), whose study focuses on OECD countries over the same period 19602000. Ahsan and Mitra (2014) use firm-level data to find that India's trade liberalization initiated in 1991 led to an increase in labor's share of revenue for small, labor-intensive firms but a reduction in this share for larger, less labor-intensive firms.

Our analysis also relates to a growing literature focused on the role of input prices as a determinant of labor shares. Bentolila and Saint-Paul (2003) show theoretically that changes in imported materials prices can influence labor shares, with the direction of influence theoretically indeterminate. Changes in imported input prices are potentially of importance for China given the large share of output value, particularly in traded goods sectors, accounted for by imported inputs. Koopman, Wang, and Wei (forthcoming) estimate that the share of domestic content in Chinese exports was about $50 \%$ before its accession to the WTO.

We turn next to a brief overview of labor market reform in China. We argue that existing evidence supports both the view that wages are market driven and that wages may reflect some element of rent sharing. The third section outlines a simple theoretical model with these elements and explains how we use this model to develop estimating equations. The fourth section describes the tariff and manufacturing census data we use to estimate labor share equations, with our results presented and discussed in the fifth section. We conclude with a consideration of the implications of our findings for the mechanisms by which trade reform influence firm's labor shares.

\section{Labor Market Reforms in China}

Extensive labor market reforms were undertaken by China during the 1990s, both to increase mobility of workers across jobs and to reduce the role of state enterprises as employers and as a source of social insurance. In 1994, China passed the Labor Law, which established the 
legal framework for market-based worker-employer relations in the context of expanded employment flexibility. In addition to providing a framework for safeguarding workers' rights, the Law calls for equal treatment of workers across ownership sectors and permits no-fault dismissal of workers. Toward the end of the decade and in recognition of the employment mobility unleashed by the Labor Law, the Chinese government began strengthening social insurance programs and improving conditions for the increasingly large number of migrant workers. Although far from fully realized, these regulatory and policy changes represent significant steps toward market-mediated labor relations.

As noted by Cai, Park, and Zhao (2008), the 1994 Labor Law facilitated the massive restructuring of state-owned enterprises, which led to layoffs of at least 10 million workers by 1997 and 27 million more from 1998 to 2004. Giles, Park, and Zhang (2005) estimate that the unemployment rate for all urban residents rose from 6.8 percent in 1996 to 11.1 percent in 2002. Workers remaining in the state sector were subject to removal of most administrative controls on the determination of wages and benefits. Thus, over the period, wages were largely freed to adjust to market-determined levels. ${ }^{4}$

In our theoretical framework, we treat the alternative or outside wage (an important component of the wage paid to a worker by a firm) as market determined, while also allowing for the possibility of rent sharing with workers in a fair wage, as distinct from union-management bargaining, context. ${ }^{5}$ The All-China Federation of Trade Unions (ACFTU) is the only national trade union federation recognized by law. It is the largest trade union federation in the

\footnotetext{
${ }^{4}$ Workers also became increasingly mobile across labor markets, particularly between urban and rural areas of the same province. Between 1995 and 2002, controls were loosened on domestic migration, including migration without formal changes in household registration (non-hukou migration).

${ }^{5}$ In our empirical work, we account for labor market reforms by identifying the effect of tariff cuts on labor shares using firm-level deviations from the general economy-wide time trends in manufacturing. This modeling choice implies that we rely for identification on changes in firm-level labor shares relative to average trends.
} 
world, claiming representation of more than 258 million workers in 5.2 million local chapters within Chinese enterprises. ${ }^{6}$ According to Trade Union Law, a union may be established in an enterprise as a result of a request from an "above-level" union or by a request from employees, although only the former requests are thought to be effective (Ge, 2013, p. 17). Chen (2009) questions whether these unions have any bargaining power, “...even though unions have come to support workers' economic demands in certain selective ways, this by no means suggests that they are capable of making claims directed at the state on behalf of workers." Given this understanding of labor unions in China, our approach allows for the possibility of rent sharing, not as a result of formal bargaining, but as a fair wage strategy to retain experienced workers.

The hypothesis that firms share surplus with workers is consistent with recent work by Nee and Opper (2012). Based on interviews and financial data from over 700 manufacturing firms in the Yangzi region, they find that "Work compensation and firm success are closely linked. Controlling for other factors (firm size, firm age, employment structure, location, and industry), there is a substantive and significant positive association between the average wage rate and a firm's return on assets (p.181)." Nee and Opper conclude, "In other words, the more profitable the firm, the higher the labor compensation and thus the better a firm's chances to recruit and retain skilled workers (p. 181)."

In our empirical work we allow for the possibility that the presence of a labor union alters a firm's response to trade liberalization. Ge (2013) agrees that Chinese unions lack a "monopoly" function, in that they have weak power in bargaining with management, but he highlights their roles as a "collective voice" for workers. This collective voice function includes mediating labor disputes, monitoring implementation of the Labor Law, providing various services and welfare benefits to employees, promoting technology innovation and employee

\footnotetext{
${ }^{6}$ Trade Unions of the World, 6th Ed. (2005), John Harper Publishing.
} 
training, and participating in corporate governance (Ge, p. 2). ${ }^{7}$ These roles allow for the possibility that a union can facilitate or resist changes to production processes, such as the introduction of imported inputs when they are made more accessible with trade liberalization. We discuss the possible influence of a labor union in the rent sharing model below and in our empirical work we test for different responses to trade liberalization by union status.

\section{Theory and Estimating Framework}

Here we present the basic economic reasoning behind the channels we expect to drive our empirical results. A more detailed model is presented in our web appendix at http://faculty.maxwell.syr.edu/dmitra/klm_webappendix.pdf .

\section{A Model of Input Choice with Rent Sharing}

Let us assume that the firm pays a fair wage to its workers because it promotes goodwill among them and minimizes worker turnover. Workers consider the wage fair if the firm shares a fraction of its profits with its employees. ${ }^{8}$ The shared fraction of profits considered fair will depend on norms. However, it could also depend on firm-specific skills and experience of the workforce and the scarcity of these skills in the labor market. Assuming the firm has some monopoly power in the product market, it will pay workers the sum of marginal revenue product and their share in rents. ${ }^{9}$ While a reduction in markups brings the marginal revenue product closer to the value of the marginal product (raises the marginal revenue product for a given value of marginal product), this reduction in markup also reduces the firm's rents which may be shared

\footnotetext{
${ }^{7}$ Empirical evidence on the effectiveness of Chinese labor unions is mixed. Using a cross-section of firms from the 2004 National Economic Census, Ge (2013) finds that union presence is positively associated with wage and benefits levels and output per worker, but negatively associated with firm profitability. Using a different data source, the 2006 Private Enterprise Survey, Lu, Tao, and Wang (2010) find no relationship between the average wage paid by the firm and union status, but a positive relationship between union presence and labor productivity.

${ }^{8}$ See Egger and Kreickemeier (2009) and Amiti and Davis (2011) for fair-wage models in the context of international trade.

${ }^{9}$ The difference between firm profits and rents is that the former is net of the overall wage bill and the latter is net of the wage bill evaluated at the outside or alternative wage. Paying workers their outside wage plus a share in profits is equivalent to paying the workers the sum of their outside wage and a somewhat smaller share in rents.
} 
with workers. Thus, a change in markup (as may arise from trade liberalization) may lead to two opposing effects on the share of labor in the value of output. It is useful to note that even in the absence of fairness concerns these outcomes would be observationally equivalent to the case with firm-union bargaining.

\section{Tariff Cuts and the Labor Share of Output}

Let us first consider the effect of lower tariffs, holding the firm's markup of price over cost constant. Because trade liberalization will make imported inputs cheaper, more of these inputs will be combined with each unit of labor. As a result, average labor productivity will rise. If these inputs are complementary to labor, through this channel we expect that, conditional on the markup, trade liberalization will increase labor's share of output.

We seek additional identification of the impact of trade liberalization on labor shares by allowing the effect to vary with access to international markets. If tariff cuts affect the marginal revenue product (MRP) of labor through the prices and variety of imports, it is likely that these pressures are strongest where access to foreign markets is strongest. To allow for this possibility, we posit that the impact of tariff cuts on labor shares moderates as the distance of the firm from international markets increases.

Next, let us consider a tariff-driven change in the markup, holding constant the firm's input choices. As mentioned above, the MRP-driven component of labor share is decreasing in the markup, but the rent-sharing component of labor share is increasing in the markup. Thus, a change in the markup may lead to an increase or decrease in labor's share. This ambiguity can be resolved empirically, and empirical results will tell whether the rent sharing channel or the MRP-driven channel is dominant. 
There are various channels through which tariff reductions can impact the markup itself. Trade liberalization may lead to lower markups due to greater import competition and reduced market power. Recent evidence (DeLoecker, Goldberg, Khandelwal, and Pavcnik, 2012), however, indicates that lower imported input prices brought about by tariff cuts are not fully passed through to final output prices and, thus, may lead to higher markups for domestic producers. DeLoecker et al. find in a sample of Indian firms that input price reductions dominate greater direct competition from imports and, thus, that trade reform leads to higher markups. As mentioned earlier, an increase in markups has effects on the two components of labor share that work in opposite directions. If rent sharing is an important component of wage determination, the labor share may increase with the markup.

We next raise the possibility that the sharing of firm profits depends on the presence or absence of a union within the enterprise. Previous authors have emphasized the role of unions in bargaining over disposition of firm rents. Using this lens, the pass-through of changes in market rents to workers may be stronger in unionized firms. Another view of unions is that they play a role on the shop floor. As workers' "collective voice," a union may prevent or make more costly the importation of inputs and may demand in-house production of these inputs. While in-house production of these inputs may protect jobs within the firm, it may raise costs or lower quality and adversely affect downstream output. The union might be boundedly rational in that it is able to see the upstream jobs saved within a firm from the in-house production but unable to see how downstream jobs are adversely affected within the firm. If the indirect effect on downstream jobs dominates the direct effect on upstream jobs, the presence of a union can weaken the positive effect of trade liberalization on the labor share, conditional on the markup. 
While wage setting in state firms has been largely deregulated, there remain important aspects of labor relations in state firms that do not conform to profit maximizing behavior. Kamal and Lovely (2012) find that labor productivity varies systematically within industries by ownership type, with state owned firms exhibiting significantly lower marginal revenue products of labor. This evidence suggests that state firms pursue employment as well as profit objectives and that their response to trade reform may be muted. To allow for this possibility, we posit that the impact of tariff cuts on labor shares varies by firm ownership type.

\section{Tariff Cuts and the Labor Share of Value Added}

This simple discussion implies that trade liberalization creates many channels by which the labor share of output may be affected. While we have discussed the share of the wage bill in total sales, many of these channels apply to the share of the wage bill in value added as well. The arguments in favor of labor share of output expansion should be even stronger when looking at value added as there is no concern that the expanding share of imported and import-competing non-factor inputs crowds out the share of labor. Cheaper non-factor inputs (due to trade liberalization) would bring about an increase in labor productivity measured by value added per worker as they would increase labor productivity measured in terms of sales per worker.

The markup channel and the rent sharing channel would work very similarly for both the labor share in output as well as in value added. In fact, the rents (and profits) defined in terms of output or, alternatively, in terms of the value added are exactly the same. So the rent-sharing based arguments above hold also for the labor share in value added as long as both output markups and value added markups move together. Of course, if all the markup increase is brought about by reductions in the prices of non-factor inputs that are passed less than 
proportionally on to consumers, then the value added markup might not move in the same direction as the output markup. However, markups of both kinds (output and value added) are measures of a firm's market power and in most cases, therefore, should be positively associated with each other. In our empirical work, we will estimate the response of both the output share of wages and the value added share and, thus, we test whether they behave in the same way with respect to our variables of interest.

\section{Estimation Strategy}

Our empirical strategy uses variation in tariff rates across industries and over time to identify the effect of trade reform on labor shares. It relies on the maintained assumption that the evolution of industry-level tariffs is exogenous to that of firm labor shares. Brandt et al. (2012) provide extensive documentation of the evolution of Chinese tariffs over 1995 to 2007 . They highlight several patterns in the data. First, there is important variation across industries. Differences in effective rates of protection across industries narrowed dramatically over time, with the $25 / 75$ quartile range dropping from approximately $20-120 \%$ in 1995 to $5-30 \%$ in $2007 .^{10}$ Secondly, Brandt et al. conclude that tariff reform over the period can be well described as tariff compression, with initially highly protected industries receiving the largest cuts. Moreover, they show that the relationship between tariff reductions and initial protection is almost one-for-one, implying that the decline in tariffs was mostly proportional and subject to little policy discretion. Additionally, tariff cuts after 2001 were fixed by China's WTO accession agreement. In light of

\footnotetext{
${ }^{10}$ Brandt $e t$ al. also show that output tariffs are higher than input tariffs, implying that effective rates of protection are higher than stated tariff rates.
} 
these findings, we control for the initial level of protection using firm fixed effects, and otherwise treat tariff cuts as exogenous to the evolution of labor shares. ${ }^{11}$

To examine the effect of trade liberalization on the share of wages in output, wages/sales, we use the following specification,

$$
\left(\frac{\text { wages }}{\text { sales }}\right)_{i t}=\alpha+\beta_{1} \text { Output Tariff } f_{j, t-1}+\theta_{i}+\theta_{t}+\varepsilon_{i t}
$$

where $i$ indexes firms, $j$ industry, and $t$ time. Output Tarif $_{j, t-1}$ captures the level of protection placed on the final good in the industry in which firm $i$ operates. ${ }^{12}$ The measure of protection is lagged one period. We include firm fixed effects, $\theta_{i}$, to control for time-invariant firm characteristics, such as skill intensity, and year effects, $\theta_{t}$, to capture economy-wide changes in factor markets, especially the outside wage. We also estimate our regressions by substituting the year effects with region by year effects, $\theta_{r t} \quad$ (where the subscript $r$ denotes region), thereby controlling for regional time variation in outside wage trends. ${ }^{13}$ Finally, $\varepsilon_{i t}$ represents an idiosyncratic error term. Because our key variable of interest, output tariff, is constructed for each 4-digit industry, we cluster standard errors at the same level of aggregation.

The coefficient $\beta_{1}$ achieved by fixed effects estimation of (1) gives us an estimate of the overall average effect of tariff reform on firm-level labor shares, relative to a non-linear time

\footnotetext{
${ }^{11}$ They also find tariff rates in 1995 and 2001 were negatively correlated with industry skill intensity, as measured using US industry characteristics, which may imply that tariff cuts were larger for unskilled labor intensive sectors. We address this possibility in our empirical strategy by our use of firm fixed effects.

${ }^{12}$ Given the high correlation $(0.72)$ we observe in the data between output tariffs and input tariffs (which we calculate using output tariffs and information from a Chinese input-output table, as described in the Appendix), it is not feasible to obtain separate estimates of the effect of these two types of tariffs.

${ }^{13}$ Regions are designated as comprised of the following provinces - (i) Coastal: Beijing, Fujian, Guangdong, Hainan, Jiangsu, Shandong, Tianjin, Zhejiang, Hebei; (ii) Inland: Shanxi, Anhui, Jiangxi, Henan, Hubei, Hunan; (iii) Northeast: Liaoning, Jilin, Heilongjiang; (iv) Southwest: Guangxi, Sichuan, Guizhou, Yunnan, Chongqing; (v) Northwest: Inner Mongolia, Tibet, Shaanxi, Gansu, Qinghai, Ningxia, Xinjiang. These regional assignments follow those used by Démurger et al. (2002), in a contribution on the role of location in China's development
} 
trend. ${ }^{14}$ As discussed in section 3 above, tariff cuts influence labor share by their impact on firm input choices and markups. Thus, our estimate of $\beta_{1}$ is an estimate of the net effect of both changes in labor input and changes in shared profits.

An important feature of China's industrial development over the past decade is the entry of new firms (Brandt and Zhu, 2010). These new firms are significantly more productive than exiting firms and this suggests that they are different from incumbent firms. To ensure that our results are not being driven by entry, in addition to using the full sample, we estimate (1) with a balanced panel comprised of firms present in the last eight years of the sample.

\section{Channels of influence: controlling for firm markups}

Tariff cuts influence both labor shares and firm markups. However, we are able to use the ASIP panel data to estimate firm markups and then include the (lagged) markup as a control in the labor share regression. In this way, we are able to estimate the effect of changes in markups on labor shares and thereby isolate it from other channels that operate on firm input choices. To do this, we estimate (1) including the estimated year-specific firm markup. This alternative specification is:

$$
\left(\frac{\text { wages }}{\text { sales }}\right)_{i t}=\alpha+\beta_{1} \text { Output Tariff } f_{j, t-1}+\beta_{2} \operatorname{Markup}_{i, t-1}+\theta_{i}+\theta_{t}+\varepsilon_{i t} \text {, }
$$

If firm's share rents with workers, we expect the estimated coefficient on firm markup, $\beta_{2}$, to be positive and significantly different from zero. We interpret the tariff coefficient, $\beta_{1}$, as the effect of the tariff on labor shares, holding the markup fixed.

Since the firm-level markup is an estimated regressor (see appendix for estimation details), we cluster standard errors at the four-digit ISIC level and we bootstrap the standard

\footnotetext{
${ }^{14}$ Given the high correlation (0.72) we observe in the data between output tariffs and input tariffs (which we calculate using output tariffs and information from a Chinese input-output table, as described in the Appendix), it is not feasible to obtain reliable estimates of the significance of these two types of tariffs.
} 
errors in all specifications that include markup. ${ }^{15}$ The markup is a function of tariff levels and we respond to this relationship in three ways. First, in estimating (2), we use a lagged value for the estimated markup to reduce concerns about contemporaneous shocks to both markups and labor shares. Secondly, we estimate (2) using five-year differences. ${ }^{16}$ These long-difference regressions allow us to instrument for the markup using the firm's material shares, as explained below. Lastly, we regress the estimated markups on both input and output tariffs, to see if the relationships found with Indian data by De Loecker et al. (2012) also hold in the Chinese case.

\section{Allowing the impact of trade reforms to vary with market access}

To test the hypothesis that the effect of tariffs attenuates as access to international markets falls, we estimate the following variation on equation (1):

$$
\begin{gathered}
\left(\frac{\text { wages }_{\text {sales }}}{i t}=\alpha+\beta_{1} \text { Output Tariff } f_{j, t-1}+\beta_{2} \text { Output Tariff }_{j, t-1} * \text { Remotenes }_{i}\right. \\
+\theta_{i}+\theta_{t}+\varepsilon_{i t} .
\end{gathered}
$$

Remoteness $_{i}$ is the distance to the nearest international port - either Shanghai, Tianjin, or Guangzhou -- from the city in which the firm $i$ is located. ${ }^{17} \mathrm{We}$ are able to test the hypothesis that less exposure to global markets reduces the impact of trade reform on firm behavior through the estimated coefficient on the interaction of output tariff and remoteness. We expect the

\footnotetext{
${ }^{15}$ In the case of labor adjustment costs (which raise the same issues in markup estimation as does the fair wage framework), De Loecker and Warzynski (2012) suggest reliance on a gross output production function and the use of information on the expenditure share of materials to estimate markups. In our regressions, the variable markup is constructed using estimated gross output production function coefficients for every two-digit CIC industry and the firm's material share of revenue. Effectively, the marginal cost in the denominator of our markup estimate uses the marginal revenue product (which is the wage exclusive of shared rents) to evaluate labor costs. Because markup is estimated, we bootstrapped errors using 400 repetitions. See Cameron and Trivedi (2005), Chapter 11, for a discussion of bootstrap replications.

${ }^{16} \mathrm{We}$ also estimate very long differences spanning our full observation period, with qualitatively similar results leading to the same inferences. These long-difference regressions are available in an on-line appendix at http://faculty.maxwell.syr.edu/dmitra/klm_webappendix.pdf .

${ }^{17}$ Distance, in 1,000 kilometers, is calculated as the arc distance between the geographic centroid of each city and that of the nearest international port, using ArcGIS software.
} 
estimated coefficient to have the opposite sign from that for the output tariff alone. Greater distance from an international port is expected to push the impact of the tariff toward zero.

\section{Labor Share of Value Added}

We test the robustness inferences drawn from estimation of (1) and (2) by replacing labor's share of sales with labor's share of value added. In switching our dependent variable to the labor share of value added, wages/VA, the output tariff may not adequately capture the impact of tariff cuts on value added, for reasons that justify use of ERP measures generally. Therefore, we estimate:

$$
\left(\frac{\text { wages }}{V A}\right)_{i t}=\alpha+\beta_{1} I_{E R P_{j, t-1}}+\theta_{i}+\theta_{t}+\varepsilon_{i t}
$$

where IERP is a calculated measure of the industry effective rate of protection and we include both firm and time fixed effects as before. We also test whether the effect of tariff cuts on the labor share of value added dissipates with distance from international ports.

\section{Allowing parameters to vary with ownership type}

To test the hypothesis that the effect of tariffs varies with ownership type, we estimate the following variation on equation (1):

$$
\begin{gathered}
\left(\frac{\text { wages }_{\text {sales }}}{i t}\right)_{i t}=\alpha+\beta_{1}{\text { Output Tarif } f_{j, t-1}}+\beta_{2} \text { Output Tarif }_{j, t-1} * \text { Remoteness }_{i} \\
+\beta_{3}{\text { Output Tarif } f_{j, t-1}}_{\text {Private }}+\beta_{4} \text { Output Tarif }_{j, t-1} * \text { Foreign }_{i} \\
+\theta_{i}+\theta_{t}+\varepsilon_{i t} .
\end{gathered}
$$

Private $_{i}$ is a dummy variable that takes the value unity if the firm is privately-owned and Foreign $_{i}$ is a dummy variable that takes the value unity if the firm is foreign-owned. State ownership is the left-out category and thus we are able to test whether the impact of tariffs differs between private and state firms and between foreign and state firms. 


\section{Allowing parameters to vary with firm union status}

To test the hypothesis that the effect of tariffs varies by a firm's union status, we estimate an additional variation on equation (2):

$$
\begin{aligned}
\left(\frac{\text { wages } \left._{\text {sales }}\right)_{i t}=\alpha}{}\right. & +\beta_{1} \text { Output Tariff } f_{j, t-1}+\beta_{2} \text { Markup }_{j, t-1} \\
& +\beta_{3} \text { Output Tariff }_{j, t-1} * \text { Union }_{i}+\beta_{4} \text { Markup }_{j, t-1} * \text { Union }_{i}+\theta_{i}+\theta_{t}+\varepsilon_{i t} .
\end{aligned}
$$

Union $_{i}$ is a dummy variable that takes the value unity if the firm hosts a registered union. We expect that the presence of a union will use its "collective voice" function to mute the impact of tariff reform on input choices, so we expect $\beta_{3}$ to take the opposite sign from $\beta_{1}$. If a union also plays a role in negotiating the extent of rent sharing, either by way of setting a fair wage norm or by exerting monopoly bargaining power, the presence of a union in the enterprise will raise the degree of rent sharing, so we expect $\beta_{4}$ to be positive. ${ }^{18}$

\footnotetext{
${ }^{18}$ Given that labor unions are subordinate to the state-party in China, we do not explore the hypothesis that trade reforms have reduced union power. Such hypotheses have focused on developed countries and are framed in terms of union bargaining over employment and wages. For example, Brock and Dobbelaere (2006) find no significant negative relationship between trade and bargaining power. Similarly, Arbache (2004), using data from Brazil, finds no significant effect of trade on bargaining power. Conversely, Dumont, Raype and Willeme (2006) use data from five EU countries and conclude that trade liberalization does reduce the bargaining power of workers.
} 


\section{Estimating firm-level markups}

Estimation of equation (2) requires a measure of the firm-level markup in each year. To create these measures, we follow the approach proposed by De Loecker et al. (2012). This approach to estimating firm-level markups relies on cost-minimization by producers and the existence of at least one variable input. In our application of the method, this variable input is taken to be material inputs, and the markup, defined as the ratio of price to marginal cost, is calculated as the ratio of the (estimated) elasticity of output with respect to material inputs and the material expenditure share, taken from the data. ${ }^{19}$ We exclude observations with markups that are above and below the 1st and 99th percentiles within each four-digit Chinese Industrial Classification (CIC) industry.

Once we have the firm-level markup estimates, we can examine their relationship to tariff levels by estimating:

$$
(\operatorname{markup})_{i t}=\alpha+\Upsilon_{1} \text { Output Tariff } f_{j, t-1}+\Upsilon_{2} \text { Input Tariff }_{j, t-1}+\theta_{i}+\theta_{t}+v_{i t},
$$

where markup is the estimated firm-level markup. As discussed above, evidence from India suggests that output tariff cuts will lower markups while input tariff cuts will increase markups and this gives us sign predictions for $\Upsilon_{1}$ and $\Upsilon_{2}$. As in the labor share regressions, we include firm fixed effects, $\theta_{i}$, to control for time-invariant firm characteristics and year effects, $\theta_{t}$, to capture economy-wide changes in product and input markets. Finally, $v_{i t}$ represents an idiosyncratic error term. Because our tariff measures are constructed for each 4-digit ISIC industry, we cluster standard errors at the same level of aggregation.

\section{Data}

The data in this study are drawn from the Annual Surveys of Industrial Production conducted by the Chinese government's National Bureau of Statistics (NBS) between 1998 and

\footnotetext{
${ }^{19}$ See Appendix for details on markup construction.
} 
2007. The Annual Surveys of Industrial Production include all state-owned enterprises and all non-state-owned firms whose annual sales exceed 5 million RMB (referred to as "above-scale" industrial firms). ${ }^{20} \mathrm{We}$ impose several restrictions on the raw data to generate our analysis dataset. We filter it to exclude observations with missing information and improbable values. We exclude those firms that employ eight or fewer workers since most improbable values are associated with smaller firms. ${ }^{21}$ We further restrict the sample to include firms that have nonnegative values for value added, total wages, total sales, total intermediate input use, gross industrial output value and capital. The final sample is an unbalanced panel spanning 1998 to 2007. Additionally, we consider a balanced panel of firms for which we have continuous data from 2000 to 2007.

Our dependent variable is the wage bill divided by total sales revenue or, alternatively, divided by value added. The labor share of sales, averaged over all firm-years, is 9.15 and the average labor share of value added is $28.17 .^{22}$ We also use information from the Annual Surveys to designate each firm as having a union present in the enterprise or not. This indicator variable is only available for firms in the 2004 Benchmark survey. Consequently, when we include union status as a regressor, we estimate our regressions using all firm-years for those firms present in the survey in 2004. Among state-owned firms in this reduced sample, $70 \%$ indicate the presence

\footnotetext{
${ }^{20}$ The NBS classifies non-state-owned enterprises to include collectively-owned enterprises, Chinese indigenous privately-owned enterprises, and foreign-owned enterprises operating in China. The annual sales cut-off for non-state firms is approximately \$ US 600,000 over this period.

${ }^{21}$ Individual businesses (getihu) are owned by private individuals or households and legally not considered enterprises. These businesses are officially limited to members of a family and up to seven non-family employees.

${ }^{22}$ To understand the extent to which our measure of labor's income share is underestimated by excluding nonwage compensation we reconstruct the measure, following Ge (2007), to include pension and health insurance, housing subsidy, and labor and unemployment insurance. Information on unemployment insurance, medical insurance, and housing provident funds are available for the years 2005-2007 only. Using these data we construct labor's non-wage compensation, add it to wage compensation, and recalculate annual average labor shares. Pooling all three years, the average labor share of sales (value added) is 9.10 (28.95). For the same years, the average labor share in sales (value added), using wage compensation only, is 8.28 (27.02). Given the small differences in these two methods, we conclude that our measure of labor shares is not sensitive to exclusion of non-wage compensation.
} 
of a labor union. Union presence is significantly less for private domestic firms, at $46 \%$, and foreign-invested firms, at $48 \%$.

Output tariff data at the HS6 digit level are obtained from the World Integrated Trade Solution (WITS). We concord these data to four-digit ISIC Rev. 3 and then to four-digit CIC. ${ }^{23}$ We use effectively applied tariffs, which are tariff rates aggregated using import shares as weights. $^{24}$

Table 1 provides a list of variables used in our regression analysis and basic descriptive statistics. The unbalanced panel contains over 1.7 million firm-year observations. The number of firms in the sample increases over time, in large part because of rapid growth in the Chinese manufacturing sector. The number of unique firms more than doubled from 129,579 in 1998 to 309,657 in 2007 . There are about 300,000 firm-year observations in the balanced panel we create using firms present throughout the period 2000 to 2007, representing 40,112 unique firms.

\section{Results}

Figure 1 illustrates trends in the average output tariff, input tariff, and industry effective rate of protection (IERP) constructed for the period 1998-2007. Both measures of protection generally decline over time. The only exception is 1999-2000, when we see a slight increase. Over the period, the average output tariff falls from $19.8 \%$ to $8.8 \%$ while the input tariff falls from $16.2 \%$ to $7.4 \%$. These trends imply a declining IERP and they mirror those found by Brandt et al. (2012) who report that output tariffs exceed input tariffs and that the difference between them falls over time. Coupled with evidence from Brandt et al. of their exogeneity,

\footnotetext{
${ }^{23}$ We thank Xuepeng Liu for sharing the output tariff data and the concordance between ISIC Rev. 3 and CIC. The concordance between HS6 and ISIC Rev.3 is available through WITS.

${ }^{24}$ The rates for 2002 are missing and we use average tariffs in 2001 and 2003 to replace the missing values. We also impute tariffs for some years by interpolation in some ISIC Rev. 3 industries. Input tariffs are constructed as a weighted average of the output tariffs with weights based on the 2002 Chinese input-output table. The construction of this variable is detailed in the Appendix.
} 
these tariff declines provide us with an ideal opportunity to look at the impact of trade liberalization on labor shares.

Figure 2 illustrates differences in the trend in average labor share for two groups of industries - those that experience above average tariff cuts over the period, and those that experience below average tariff cuts over the period. Both industry groups experience fairly steady downward trends in average labor share, as the overall share of labor in national income falls throughout the period. While we note this economy-wide decline in labor shares, our analysis addresses deviations from economy-wide trends and their relationship to tariff cuts.

As shown in Figure 2, the ratio of the average labor share in high-tariff-cut industries relative to that in the low-tariff-cut industries begins only slightly above unity in 1998 , but rises to almost 1.25 by 2007 . This pattern is consistent with our regression results below in that labor shares in firms facing deeper tariff cuts increased relative to economy-wide trends (i.e., at the firm level, changes in labor shares and changes in tariffs are negatively correlated). Figure 2 also suggests that industries with larger tariff drops initially had a slightly higher average wage bill share, raising concern about the relation between tariff cuts and initial conditions. We address this concern in two ways in our empirical work: first, by including firm fixed effects in our labor share regression and, secondly, by taking long differences of the data and including initial tariffs among the regressors.

Figure 3 illustrates the trend in the markup, which we estimate using firm-level data and then average for the full sample in each year. Interestingly, the markup trend bottoms out in 2001, the year China enters the WTO and begins rising thereafter as the accession-related tariff cuts are implemented. It is important to note that China's WTO accession did not generally result in lower tariffs for Chinese exporters as China already enjoyed most-favored-nation 
(MFN) rates in trading with WTO members. ${ }^{25}$ For Chinese domestic producers, the most important trade-related aspect of WTO accession was the reduction in Chinese tariffs.

Table 2 provides the results of estimating equation (1): the regression of labor shares of sales on (lagged) output tariffs using both the full unbalanced panel (columns 1 and 2) and a balanced panel (columns 3 and 4). We use both panels to ensure that our results are not being driven by the rapid entry of new firms over the sample period. We include firm fixed effects to control for time-invariant cross-sectional variation in labor shares. Because it is difficult to separate the impact of tariff changes from ongoing domestic reforms that also influence the outside wage, we estimate (1) using year dummies, as shown in columns 1 and 3 of Table 2 or region-by-year dummies, as shown in columns 2 and 4. The inclusion of these year dummies allows us to interpret the estimated coefficient on output tariffs as the effect of trade reform on labor shares, relative to economy-wide trends. ${ }^{26}$

Regardless of the set of controls or sample used, the estimated coefficient on the lagged output tariff is always negative and statistically significant. The estimated coefficients of -1.993 in column (2), estimated with the full sample and region-year fixed effects, implies that a one standard deviation decline in the output tariff leads to a 0.024 standard deviation increase in the labor share relative to the region-wide trends. For the balanced panel, the effect is larger: the

\footnotetext{
${ }^{25}$ Handley and Limão (2013) note that U.S. tariffs on Chinese imports did not change with China's WTO accession. Rather, they argue that the resolution of uncertainty over the annual granting of MFN status by the United States to China was the key aspect of accession affecting Chinese export markets. Another policy change over our sample time period was expiration of the Multi-Fiber Arrangement (MFA). In our web appendix, available at http://faculty.maxwell.syr.edu/dmitra/klm webappendix.pdf, we present regression results estimated by excluding textiles and apparel firms. Our inferences regarding tariffs and labor shares are highly robust to this exclusion. These additional findings indicate that our conclusions are not driven by the MFA expiration, which was the only real reduction of barriers to imports from China during our sample period.

${ }^{26}$ Some researchers, including Bai and Qian (2011), also include a measure of the capital stock in labor share regressions. We choose not to do so because tariff changes should lead to changes in all factor input choices and if we control for these, or control only for capital inputs, we remove that part of the response from the tariff coefficient. We include firm fixed effects, so we do control for the time-invariant capital stock of the firm. Estimating equations (1) and (2) including a measure of firm-level capital and, alternatively, capital and firm size, does not affect the signs or significance of our variables of interest.
} 
estimated coefficient (column 4) of -3.096 implies a one standard deviation increase in the labor share of 0.035 relative to region-wide trends.

We now turn to the effect of trade reform on labor shares, controlling for the firm's markup. To explore the relationship between our markup estimates and tariff levels, Table 3 provides results for regression of the estimated firm-level markups on both the (lagged) output tariff and (lagged) input tariff. As controls, we include firm fixed effects and year effects or, alternatively, firm fixed effects and region-year fixed effects. The two tariff measures are highly correlated, but given previous evidence from India we include both in the regression to explore the direction of influence. Consistent with the evidence from India, we find a positive relationship between the firm's markup and the industry output tariff and a negative relationship between the markup and the industry input tariff. Because the two tariff series move in the same direction and by approximately the same magnitude, the much larger (in absolute value) coefficient on the input tariff implies that trade reform lead to higher markups for Chinese firms.

These results are qualitatively similar to those reported by De Loecker et al. (2012, Table 9) where Indian firm-level markups are positively correlated with output tariffs but negatively correlated with input tariffs. The positive coefficient on output tariffs is consistent with the view that import competition leads to output price declines and reduced markups. The negative coefficient on the input tariff is consistent with improved access to cheaper and more varied imported inputs, which reduce costs but are not fully passed-through to prices, thereby raising firm-level markups. Although the Chinese data does not permit us to observe ex-factory prices, our findings are consistent with this documented pricing behavior in India.

When we estimate equation (2) by including the estimated markup (lagged one period) as an additional control in the labor share regressions, as seen in Table 4, the estimated coefficient 
on the output tariff remains negative and of similar magnitude, although only significant in the full sample estimates. The beta coefficient for the estimated output tariff coefficient in column 2 indicates that a one standard deviation reduction in the output tariff, holding the firm's markup constant, raises labor share by 0.03 of a standard deviation. The markup itself has a positive and highly significant coefficient, suggesting that a part of the additional rent created by trade liberalization is passed along to labor. The estimated markup coefficient in column 2 of 0.22 implies that a one standard deviation increase in the markup raises the labor share of sales by 0.008 of a standard deviation.

Comparing the results from the unbalanced panel to the balanced panel in Table 4, we find that the estimated impact of output tariffs on the labor share of incumbent firms is larger (a coefficient of -3.033 versus -1.993 , using estimates that include firm and region-year fixed effects), but qualitatively the same. Indeed, the beta coefficient implies that a one standard deviation decline in the output tariff leads to a 0.035 standard deviation increase in the labor share of incumbents, very similar in magnitude to the impact estimated for the full sample. We also find evidence of rent sharing, as indicated by the positive and highly significant estimated coefficient on the markup. In contrast to the full sample, these coefficients suggest that incumbents pass a larger share of rents along to workers - the beta coefficient rises from 0.008 for the full panel to 0.022 for the balanced panel.

We allow for heterogeneous effects by interacting the output tariff with the firm's remoteness, as measured by its distance to the nearest international port, as shown in Table 5. These results provide strong statistical support for spatial differences in the effect of trade liberalization on firms. With or without controlling for firm markups, we find that the positive impact of tariff cuts on labor shares is attenuated by distance from an international port. 
Comparing Table 4, column 1, results to Table 5, column 4, we see that accounting for a spatial dimension does not change the sign, magnitude, or significance of the markup variable.

However, the average effect of the tariff found in Table 4 is seen to mask much spatial variation: the estimated coefficients in Table 5, column 4, imply a marginal effect of the tariff on labor share of -2.152 for firms in Fuzhou, located in the Coastal region, a marginal effect of -1.978 for Huangzhou, located in the Central region, -0.426 for Xi' an, located in the Northwestern region, and 1.569 for Chengdu, located in the Southwestern region. Tariff cuts have their strongest positive impact on labor shares in those regions most exposed to international trade and, indeed, our estimates suggest that tariff cuts reduce labor shares in interior provinces.

Given that tariff cuts reduce the cost of imported materials, increases in the labor share of sales may not translate into increases in the labor share of domestic value added. Table 6 checks the applicability of our findings to the labor share of value added instead of labor share of sales. With this switch in the dependent variable, we substitute the industry effective rate of protection (IERP) for the output tariff. Looking across the columns, we see that the estimated coefficient for IERP is negative and significant, whether or not we control for firm-level markup. We continue to find significant spatial variation in the impact. The estimated coefficients shown in column 4 imply a marginal effect of -0.761 for firms in Fuzhou, located in the Coastal region, 0.658 for Huangzhou, located in the Central region, 0.256 for Xi' an, located in the Northwestern region, and 1.432 for Chengdu, located in the Southwestern region. Compared to the results shown in Table 5, a decrease in the effective rate of protection raises labor's share of value added, but the positive impact falls off more quickly with distance than is the case for labor's share of sales. In sum, substituting labor share of value added for labor share of sales as the dependent variable leads to the same conclusion: reductions in protection lead to higher labor 
shares, ceteris paribus, and this effect attenuates with distance from international ports. We also continue to find robust evidence that firms pass a share of rents to workers.

Because available evidence suggests that state firms may have less flexibility in adjusting employment, we expect tariff cuts to have a larger impact on non-state firms than on those in the state sector. Table 7 allows the impact of trade protection on the labor share of sales to differ for domestic private firms and for foreign-invested enterprises from that for state firms. Looking at column 2, which includes firm and year effects, we find that the impact of protection on domestic private firms is not significantly different from that estimated for state firms. The impact of tariff cuts on the labor share of sales in foreign-owned firms, however, is much larger: for a firm located in a port city, the estimated coefficient for output tariff increases from -0.032 to -0.126 , almost a $300 \%$ increase in magnitude. It may be that foreign firms use larger shares of imported intermediates or are better able to compete with imported varieties. We leave for future research an exploration of these differences between these firm types.

Table 8 provides evidence concerning the role of labor unions in adjustment to liberalization. Estimating our regression on the entire sample, as in columns 1 and 2, we find that lower output tariffs raise labor share for all firms, but the magnitude of the effect is smaller when a union is present. This result is consistent with a process in which the union uses its "collective voice" to slow the introduction of imported intermediates, but such an interpretation cannot be directly tested with our data. Given that most state-owned firms have a union present, we estimate the regression separately for private enterprises (columns 3 and 4 ) and for foreigninvested enterprises (columns 5 and 6). As for the full sample, we find that the effect of tariff cuts is smaller for union firms. Interestingly, we find a significant relationship between firm markups and labor shares only in private firms in which a union is present. In contrast, foreign- 
invested firms with a union present exhibit no significantly different rent sharing behavior than do those without a union present. One possible explanation is that foreign firms already pay a wage premium tied to profitability (Harrison and Scorse, 2009), and thus do not need to offer further concessions regardless of whether or not a union is present in the enterprise.

Our final empirical explorations consider long-differences in the data. These may be interpreted as long-run effects and they provide additional support for a causal interpretation of our findings. ${ }^{27}$ We calculate five-year differences in the labor shares and regress them on fiveyear differences in lagged output tariffs. We also include the change in markups, which given output elasticities that do not vary over time are measured by the negative of the change in log material share, to test the robustness of our findings regarding rent sharing. In additional specifications, we again allow the impact of output tariffs to attenuate with remoteness. ${ }^{28}$

Table 9 presents results of the five-year difference regressions. As in the level regressions, cuts in output tariffs are associated with increases in the labor share of sales. Without additional controls, as shown in column 1, the estimated coefficient on the change in output tariff implies that a one percentage point cut in the output tariff raises labor share by 0.05 percentage points. This estimate is about double that implied by the level regressions shown in Table 3, and it suggests that the long-run impact of tariff cuts may exceed the one-year impact. Again, we find that the estimated coefficient on output tariff is not much affected by the inclusion of the firm-level markup. The markup continues to have a positive relationship with labor's share of sales. When we allow the tariff coefficient to vary with remoteness, we again find that weaker market access significantly reduces the pro-labor impact of tariff cuts.

\footnotetext{
${ }^{27}$ Because we estimate the level equations with firm fixed effects, they are close to estimates obtained from first-difference regressions. Consequently, we interpret differences between the five-year-difference results and the fixed-effect regression results as differences between short-run and long-run impacts.

${ }^{28} \mathrm{We}$ also estimate nine-year differences and obtain qualitatively similar and statistically significant results. These regression results are available at http://faculty.maxwell.syr.edu/dmitra/klm_webappendix.pdf .
} 
Our last regressions are shown in Table 10, where we estimate five-year differences with initial tariff levels included as additional controls. Evidence assembled by Brandt et al. (2012) suggests a policy of tariff compression, in which case those industries receiving the largest absolute cuts had the highest initial tariffs. The results in Table 10 show that controlling for the initial tariff level does not alter our findings regarding the significant and positive impact of tariff cuts on labor shares. The initial tariff level is never a significant determinant of long-run changes in labor shares.

\section{Conclusion}

Previous research has found that the impact of trade liberalization on firm behavior depends on local production conditions. China is unlike many other countries in its extensive use of imported materials, lack of effective collective bargaining, and disproportionate presence of state enterprises in protected sectors. Drawing upon a theoretical model that permits trade reform to affect firm's input choices and the extent of rent sharing, we find support for a positive and significant effect of liberalization on the labor share of sales and the labor share of value added, operating through both channels. These results imply that workers share part of the gains for manufacturing firms from China's WTO accession documented by Brandt et al. (2012).

The estimated economic magnitude of tariff cuts on labor shares is significant. Using the regression results shown in Tables 5 and 6, column 3, we estimate the labor share for every firm in 2007 using the counterfactual 1999 tariff rates, and weight the firm shares by employment. Assuming the same secular trend in economy-wide labor shares, we estimate that the actual weighted labor share of sales is $12 \%$ (1.1 percentage points) higher in 2007 than it would have been in the absence of trade reform. Further, we estimate that the labor share of value added is $11 \%$ ( 3 percentage points) higher in 2007 than it would have been in the absence of trade reform. 
We cannot fully investigate the mechanisms by which firms altered input choices because the Chinese manufacturing census does not provide information on imported intermediates. Our results are consistent, however, with complementarity between domestic labor and imported intermediates, so that lower tariffs on imported inputs lead to higher labor productivity and labor share of value. Previous research has shown the importance of intermediate imports to domestic capabilities. In their study of Indian trade liberalization, Goldberg, Khandelwal, Pavcnik, Topalova (2010) find that new imported varieties generated an annual $4.7 \%$ decline in the imported input price index, and that firms' access to new imported inputs increased their ability to manufacture new products. Khandelwal and Topalova (2011) further find that lower tariffs on final goods, as well as access to better inputs, due to lower input tariffs, increased firm-level productivity, with input tariffs having a larger impact. Given the productivity enhancing effect of trade reforms in China, it is likely that some share of these gains came through lower input prices and our results suggest that this contributed to higher labor shares.

Other possible explanations for our findings also bear further investigation. An important alternative to input complementarity focuses on skill upgrading. Firms that face increased import competition may respond by increasing the education or experience of the workforce. Recent evidence from Indonesia suggests skill upgrading may be important: Kasahara, Liang, and Rodrique (2013) find that importing intermediates increases the relative demand for educated workers at the plant level. More highly educated or experienced workers earn higher wages and, thus, may be one reason for higher wage bills in liberalized sectors. Such responses are consistent with our interpretation of the coefficient we estimate for the output tariff as evidence of changes in firms' input choices, with a focus on changes in the type of worker hired. 
Our empirical findings also suggest that firms share rents with workers, a result that may be somewhat surprising given the view that workers have no bargaining power in China.

However, our results are consistent with the recent empirical contributions of Ge (2013) and Nee and Opper (2012). By examining the response of firms depending on whether or not there is a union present in the enterprise, we are able to offer additional evidence on how unions influence firm behavior in the developing world. 


\section{Appendix}

\section{Construction of Markups}

The method proposed by De Loecker, Goldberg, Khandelwal, and Pavcnik (2012) to estimate markups requires estimation of a production function but does not require the specification of how firms compete in the product market. To implement the method with the ASIF, we begin by estimating production functions for every two-digit CIC industry to obtain output elasticities and input shares in total revenue.

Assuming a translog production function, the estimating equation is,

$$
\begin{gathered}
y_{i t}=\beta_{0}+\beta_{l} l_{i t}+\beta_{l l} l_{i t}^{2}+\beta_{k} k_{i t}+\beta_{k k} k_{i t}^{2}+\beta_{m} m_{i t}+\beta_{m m} m_{i t}^{2}+\beta_{m l} m l_{i t}+\beta_{k l} k l_{i t}+ \\
\beta_{m k} m k_{i t}+\omega_{i t}+e_{i t}
\end{gathered}
$$

where $y_{i t}$ is $\log$ of real gross industrial output value for firm $i$ in period $t, l_{i t}, m_{i t}, k_{i t}$ are the $\log$ values of labor, real intermediate inputs (or materials), and real capital, $\omega_{i t}$ is the component of

productivity shock observed by the firm but not the econometrician, and $e_{i t}$ is the component of productivity shock that is unobserved by both the firm and the econometrician.

To control for $\omega_{i t}$, the Olley and Pakes (1996) method employs the investment decision function. This is based on the assumption that future productivity is strictly increasing with respect to current productivity, so that conditional on current capital usage, firms that observe a positive productivity shock in period $t$ will invest more in that period.

$$
y_{i t}=\beta_{l} l_{i t}+\beta_{l l} l_{i t}^{2}+\beta_{m} m_{i t}+\beta_{m m} m_{i t}^{2}+\beta_{m l} m l_{i t}+\emptyset\left(i_{i t}, k_{i t}, l_{i t}, m_{i t}\right)+e_{i t}
$$

where $i_{i t}$ is $\log$ investment and

$$
\emptyset\left(i_{i t}, k_{i t}, l_{i t}, m_{i t}\right)=\beta_{0}+\beta_{k} k_{i t}+\beta_{k k} k_{i t}^{2}+\beta_{k l} k l_{i t}+\beta_{m k} m k_{i t}+h\left(i_{i t}, k_{i t}\right)
$$

and $h($.$) is approximated by a second order polynomial series in capital and investment so that,$

$$
\emptyset\left(i_{i t}, k_{i t}, l_{i t}, m_{i t}\right)=\beta_{0}+\beta_{k} k_{i t}+\beta_{k k}\left(2 k_{i t}^{2}\right)+\beta_{k l} k l_{i t}+\beta_{m k} m k_{i t}+\beta_{i} i_{i t}+\beta_{i i} i_{i t}^{2}+\beta_{k i} k i_{i t} .
$$


Equation (2) is estimated using OLS and the coefficient estimates for the variable inputs will be consistent because $h($.$) controls for unobserved productivity.$

To control for selection bias, a survival probability, $\widehat{P}_{i t}$, is estimated for each firm as a function of lagged $i$ and $k$, their squares and cross products. To consistently estimate the capital coefficients we regress,

$$
\begin{array}{r}
y_{i t}-\hat{\beta}_{l} l_{i t}-\hat{\beta}_{l l} l_{i t}^{2}-\hat{\beta}_{m} m_{i t}-\hat{\beta}_{m m} m_{i t}^{2}-\hat{\beta}_{m l} m l_{i t}= \\
\beta_{k} k_{i t}+\beta_{k k}\left(2 k_{i t}^{2}\right)+\beta_{k l} k l_{i t}+\beta_{m k} m k_{i t} \\
+g\left(\widehat{\emptyset}_{t-1}-\beta_{k}^{*} k_{i t-1}-\beta_{k k}^{*}\left(2 k_{i t-1}^{2}\right)-\beta_{k l}^{*} k l_{i t-1}-\beta_{m k}^{*} m k_{i t-1}, \hat{P}_{i t}\right)+e_{i t}
\end{array}
$$

where $g($.$) is approximated by a second order polynomial series in \left(\widehat{\emptyset}_{t-1}-\beta_{k}^{*} k_{i t-1}-\right.$ $\beta k k * 2 k i t-12-\beta k l * k l i t-1-\beta m k * m k i t-1$ and Pit.

The coefficients, $\hat{\beta}_{l}, \hat{\beta}_{l l}, \hat{\beta}_{m}, \hat{\beta}_{m m}$, and $\hat{\beta}_{m l}$ are consistent estimates for the variables from the first stage. $\beta_{k}^{*}, \beta_{k k}^{*}, \beta_{k l}^{*}$, and $\beta_{m k}^{*}$ can be any candidate value so that a prediction for the unobserved productivity can be computed up to a scalar constant. We use a non-linear estimation routine in this stage and set the initial parameters to the OLS estimates from the first stage.

Once all coefficients of the translog production function have been consistently estimated, the markups are estimated as the output elasticity, $\hat{\theta}_{i t}^{j}$, with respect to an input, $j$, divided by the input's share in revenue, $\alpha_{i t}^{j}$. Since we focus on material markups, output elasticity for material is given by $\hat{\theta}_{i t}^{M}=\hat{\beta}_{m}+2 \hat{\beta}_{m m} m_{i t}+\hat{\beta}_{l m} l_{i t}+\hat{\beta}_{m k} k_{i t}$ and the markup with respect to materials is given by $\hat{\theta}_{i t}^{M} / \alpha_{i t}^{M}$, where $\alpha_{i t}^{M}$ is drawn from the data. 


\section{Input Tariff Construction}

Data on output tariffs available at the HS6 product level are converted to ISIC Rev. 3

industry level. These data are linked to the Chinese firm level data using a concordance between the four-digit Chinese Industrial Classification (CIC) and ISIC Rev. 3. For majority of the manufacturing industries at the CIC level, there is a many to one mapping between CIC and ISIC. $^{29}$ Once output tariffs have been assigned to each four-digit CIC, they are aggregated to the five-digit IO sector level using output in 2003 as weights (Du, Harrison, Jefferson, 2011).

The following steps were carried out to construct the input tariffs. First, the 2002 Chinese input-output (IO) table was used to generate an input-output share matrix. The IO table consists of 122 sectors of which 71 belong to manufacturing. A typical cell $i j$ in this matrix lists the share of inputs in industry $i$ that come from industryj. These shares are multiplied by output tariffs as follows,

$$
\text { Input Tariff } f_{i}=\sum_{j} s_{i j} * \text { Output Tariff } f_{j}
$$

The weights $s_{i j}$ represents the share from the IO share matrix. For instance, if industry $i$ uses $70 \%$ plastic and $30 \%$ glass in its production, then it faces an input tariff that gives a weight of $70 \%$ to the output tariff on plastic and $30 \%$ to the output tariff on glass.

\footnotetext{
${ }^{29}$ Four-digit CIC industries of 1529 "Manufacture of Fruit Wine", 1533 "Manufacture of Fruit and Vegetable Juice", and 1469 "Manufacture of Other Condiments and Fermented Products" map into two different ISIC industries each. Specifically, 1529 maps into 1552 "Manufacture of wines" and 1551" Distilling, rectifying and blending of spirits; ethyl alcohol production from fermented materials"; 1533 maps into 1554 "Manufacture of soft drinks; production of mineral waters" and 1513 "Processing and preserving of fruit and vegetables"; and 1469 maps into 1514 "Manufacture of vegetable and animal oils and fats" and 1549 "Manufacture of other food products n.e.c.". The output tariffs at the ISIC level are weighted equally to arrive at output tariffs at the four-digit CIC level. For example, a weight of 0.5 is assigned to output tariffs in ISIC sectors 1552 and 1551 to create an output tariff measure for four-digit CIC industry 1529.
} 


\section{References}

Ahsan, R. and D. Mitra (2014), 'Trade Liberalization and Labor's Slice of the Pie: Evidence from Indian Firms," Journal of Development Economics, forthcoming.

Amiti, M. and D.R. Davis (2011), “Trade, Firms, Wages: Theory and Evidence," Review of Economic Studies 79, 1-36.

Arbache, J. S. (2004), “Does Trade Liberalization Always Decrease Union Bargaining Power?" Economica 5(1): 99-121.

Bai, C.E. and Z. Qian (2010), “The Factor Income Distribution in China: 1978-2007,” China Economic Review 21: 650-670.

Bentolila, S., and G. Saint-Paul (2003), "Explaining Movements in the Labor Share," The B.E. Journal of Macroeconomics, 3(1).

Brandt, L. and X. Zhu (2010), “Accounting for China's Growth,” Unpublished manuscript, University of Toronto.

Brandt, L., J. Van Biesebroeck, L. Wang, and Y. Zhang (2012), "WTO Accession and Performance of Chinese Manufacturing Firms," Unpublished manuscript, University of Toronto.

Brock, E and S. Dobbelaere (2006), "Has International Trade Affected Workers' Bargaining Power?" Review of World Economics 142(2): 233-266.

Dumont, M, G. Rayp and P. Willeme (2006), "Does Internationalisation Affect Union Bargaining Power? An Empirical Study for Five EU-Countries," Oxford Economic Papers 58(1): 77-102.

Cai, F., A. Park and Y. Zhao (2008), "The Chinese Labor Market in the Reform Era," in L. Brandt, \& T.G. Rawski (eds.), China's Great Economic Transformation (New York: Cambridge University Press).

Cameron, A.C., and P.K. Trivedi (2005), Microeconometrics: Methods and Applications, (Cambridge and New York, Cambridge University Press).

Chen, F. (2009), "Union Power in China: Source, Operation, and Constraints," Modern China 35(6): 662-89

De Loecker, J. and F. Warzynski (2012), "Markups and Firm-Level Export Status," American Economic Review 102: 2437-2471.

De Loecker, J., P. Goldberg, A. Khandelwal and N. Pavcnik (2012), "Prices, Markups, and Trade Reform," NBER Working Paper No. 17925. 
Du, L., A. Harrison and G. Jefferson (2011), "Do Institutions Matter for FDI Spillovers? The Implications of China's Special Characteristics," NBER Working Paper No. 16767.

Egger, H. and Kreickemeier, U. (2009), "Firm Heterogeneity and the Labor-Market Effects of Trade Liberalization," International Economic Review 50(1) 187-216.

Ge, Y. (2013), “What Do Unions Do in China?” Contemporary Economic Policy doi:10.1111/coep.12012.

Giles, J., A. Park and J. Zhang (2005), "What is China's True Unemployment Rate?" China Economic Review 16: 149-170.

Goldberg, P., A. Khandelwal, N. Pavcnik and P. Topalova (2010), "Imported Intermediate Inputs and Domestic Product Growth: Evidence from India," Quarterly Journal of Economics, 125(4): 1727-1767.

Guscina, A. (2006), "Effects of Globalization on Labor's Share in National Income," IMF Working Paper \#WP/06/294.

Handley, K. and N. Limão (2013), "Policy Uncertainty, Trade and Welfare: Theory and Evidence for China and the U.S.," NBER Working Paper No. 19376 (August).

Harrison, A. E. (2005), “Has Globalization Eroded Labor's Share? Some Cross Country Evidence," MPRA Paper No. 39649, University of Munich.

Harrison, A., and J. Scorse (2009), "Do Foreign Firms Pay More? Evidence from the Indonesian Manufacturing Sector," in R. Kanbur and J. Svejnar (eds.), Labor Markets and Economic Development (New York: Routledge Press).

International Labour Organization (2013), Global Wage Report 2012/13: Wages and Equitable Growth, International Labour Organization, Geneva.

Kamal, F. and M.E. Lovely (2012), "Labor Allocation in China: Implicit Taxation of the Heterogeneous Non-State Sector,” CESifo Economic Studies, doi:10.1093/cesifo/ifs026.

Kasahara, H., Y. Liang, and J. Rodrique (2013), "Does Importing Intermediates Increase the Demand for Skilled Workers? Plant-Level Evidence from Indonesia," CESifo Working Paper No. 4463 (October).

Khandelwal, A. and P. Topalova (2011), "Trade Liberalization and Firm Productivity: The Case of India," Review of Economics and Statistics, 93(3): 995-1009.

Koopman, Z. Wang, R., S.J. Wei (forthcoming) "Estimating Domestic Content in Exports When Processing Trade is Pervasive," Journal of Development Economics.

Lu, Y., Z. Tao, and Y. Wang (2010), "Union Effects on Performance and Employment Relations: Evidence from China," China Economic Review 21: 202-210. 
Nee, V. and S. Opper (2012), Capitalism from Below: Markets and Institutional Change in China, (Cambridge, MA: Harvard University Press).

Olley, S. and A. Pakes (1996), "The Dynamics of Productivity in the Telecommunications Equipment Industry," Econometrica 64: 1263-98.

Qian, Z. and X. Zhu (2012), "Why Is Labor Income Share So Low in China?” Unpublished presentation at the Pennsylvania State University, May 9.

Yang, D. T., V. Chen, and R. Monarch (2010), "Rising Wages: Has China Lost its Global Labor Advantage?" Pacific Economic Review 15: 482-504. 
Table 1: Variable Definitions and Summary Statistics

\begin{tabular}{|c|c|c|c|}
\hline Variable & Definition & Mean & St. Dev. \\
\hline \multicolumn{4}{|l|}{ Firm Level } \\
\hline Wage Bill/Sales & Share of wage bill in total sales $\mathrm{x} 100$ & 9.149 & 10.034 \\
\hline Wage Bill/Value Added & Share of wage bill in total value added $\mathrm{x} 100$ & 28.166 & 21.389 \\
\hline Remoteness & $\begin{array}{l}\text { Distance from city in which firm is located to nearest port } \\
\text { (Shanghai, Tianjin, or Guangzhou) in } 1,000 \mathrm{~km}\end{array}$ & 0.380 & 0.357 \\
\hline Markup & $\begin{array}{l}\text { Ratio of price to marginal cost, estimated using translog } \\
\text { production functions (See Appendix 1) }\end{array}$ & 1.296 & 0.353 \\
\hline Material Share & $\begin{array}{l}\text { Log of the share of intermediate inputs in gross industrial } \\
\text { output value }\end{array}$ & 0.747 & 0.134 \\
\hline Union & $\begin{array}{l}\text { Categorical variable that takes the value } 1 \text { if a union is present } \\
\text { in the enterprise and } 0 \text { otherwise }\end{array}$ & 0.519 & 0.500 \\
\hline \multicolumn{4}{|l|}{ Industry Level } \\
\hline Output Tariff & $\begin{array}{l}\text { Applied tariff rates weighted by imports at the four-digit ISIC } \\
\text { Rev. } 3 \text { level; concorded to four-digit CIC by authors. }\end{array}$ & 0.126 & 0.116 \\
\hline $\begin{array}{l}\text { Industry Effective Rate of } \\
\text { Protection (IERP) }\end{array}$ & $\begin{array}{l}\text { Effective rate of protection at the four-digit ISIC Rev. } 3 \text { level; } \\
\text { concorded to four-digit CIC by authors. }\end{array}$ & 0.194 & 0.366 \\
\hline Input Tariff & $\begin{array}{l}\text { See text for details on construction of this variable at the five- } \\
\text { digit IO level; concorded to four-digit CIC by authors. }\end{array}$ & 0.104 & 0.064 \\
\hline
\end{tabular}


Table 2: Labor Share of Sales and Output Tariffs, by Panel Type

\begin{tabular}{lcccc}
\hline & \multicolumn{2}{c}{ Unbalanced Panel } & \multicolumn{2}{c}{ Balanced Panel } \\
\hline & $(1)$ & $(2)$ & $(3)$ & $(4)$ \\
\hline Lag Output Tariff & $-2.039 *$ & $-1.993 * *$ & $-3.271 * *$ & $-3.096 * *$ \\
& $(1.060)$ & $(0.904)$ & $(1.515)$ & $(1.291)$ \\
Constant & & & & \\
& $9.084 * * *$ & $8.632 * * *$ & $9.783 * * *$ & $9.644 * * *$ \\
Observations & $(0.238)$ & $(0.235)$ & $(0.255)$ & $(0.249)$ \\
Adjusted $R^{2}$ & $1,768,083$ & $1,768,083$ & 309,467 & 309,467 \\
Firm FE & 0.62 & 0.62 & 0.65 & 0.65 \\
Year FE & $\mathrm{Y}$ & $\mathrm{Y}$ & $\mathrm{Y}$ & $\mathrm{Y}$ \\
Region-Year FE & - & - & $\mathrm{Y}$ & - \\
\hline Notes: The dependent variable is $($ wage bill/sales x 100$)$ & - & $\mathrm{Y}$ \\
\hline
\end{tabular}

Notes: The dependent variable is (wage bill/sales $\mathrm{x} 100$ ).

The unbalanced panel spans 1998 through 2007. The balanced panel spans 2000 through 2007.

Standard errors are clustered at the four-digit ISIC level and in specifications that include firm-level markups, bootstrapped using 400 repetitions. Significance: $* 10 \%$, **5\%, ***1\%. 
Table 3: Markups and Trade Liberalization

\begin{tabular}{lcc}
\hline & $(1)$ & $(2)$ \\
& Markup & Markup \\
\hline Lag Output Tariff & 0.0685 & 0.0651 \\
& $(0.051)$ & $(0.052)$ \\
Lag Input Tariff & $-0.476^{* * *}$ & $-0.461 * * *$ \\
& $(0.142)$ & $(0.143)$ \\
Constant & $1.343^{* * *}$ & $1.347 * * *$ \\
& $(0.018)$ & $(0.020)$ \\
\hline Observations & $1,691,791$ & $1,691,791$ \\
Adjusted $R^{2}$ & 0.45 & 0.45 \\
Firm FE & $\mathrm{Y}$ & $\mathrm{Y}$ \\
Year FE & $\mathrm{Y}$ & - \\
Region-Year FE & - & $\mathrm{Y}$ \\
\hline
\end{tabular}

Notes: The dependent variable is markup. See text for details on how markups are calculated from firm-level data. Outliers in the 99th and 1st percentile of the markup distribution are excluded. The regressions are run on an unbalanced panel from 1998-2007. Standard errors are clustered at the four-digit ISIC level.

Significance: $* 10 \%, * * 5 \%, * * * 1 \%$. 
Table 4: Labor Share of Sales and Output Tariffs, Controlling for Firm Markup, by Panel Type

\begin{tabular}{|c|c|c|c|c|}
\hline & \multicolumn{2}{|c|}{ Unbalanced Panel } & \multicolumn{2}{|c|}{ Balanced Panel } \\
\hline & (1) & (2) & (3) & (4) \\
\hline Lag Output Tariff & $\begin{array}{c}-2.534 \\
(1.725)\end{array}$ & $\begin{array}{c}-2.475 * * \\
(1.184)\end{array}$ & $\begin{array}{l}-3.221 \\
(2.228)\end{array}$ & $\begin{array}{c}-3.033 \\
(1.879)\end{array}$ \\
\hline Lag Markup & $\begin{array}{l}0.213 * * * \\
(0.071)\end{array}$ & $\begin{array}{c}0.220 * * * \\
(0.049)\end{array}$ & $\begin{array}{c}0.558 * * * \\
(0.193)\end{array}$ & $\begin{array}{c}0.566 * * * \\
(0.185)\end{array}$ \\
\hline Constant & $\begin{array}{c}8.578 * * * \\
(0.442)\end{array}$ & $\begin{array}{c}8.130 * * * \\
(0.429)\end{array}$ & $\begin{array}{c}8.851 * * * \\
(0.466)\end{array}$ & $\begin{array}{c}8.638 * * * * \\
(0.447)\end{array}$ \\
\hline Observations & $1,310,984$ & $1,310,984$ & 291,795 & 291,795 \\
\hline Adjusted $R^{2}$ & 0.65 & 0.65 & 0.66 & 0.66 \\
\hline Firm FE & $\mathrm{Y}$ & Y & $\mathrm{Y}$ & $\mathrm{Y}$ \\
\hline Year FE & $\mathrm{Y}$ & - & Y & - \\
\hline Region-Year FE & - & $\mathrm{Y}$ & - & $\mathrm{Y}$ \\
\hline $\begin{array}{l}\text { Notes: The dependent } \\
\text { the markup distributic } \\
\text { panel spans } 2000 \text { thro } \\
\text { specifications that inc } \\
\text { Significance: } * 10 \% \text {, }\end{array}$ & $\begin{array}{l}\text { is (wage bi } \\
\text { cluded. The } \\
\text { 7. Standard } \\
\text { n-level mark } \\
* 1 \% \text {. }\end{array}$ & $\begin{array}{l}\text { X 100). Outl } \\
\text { nced panel s } \\
\text { re clustered } \\
\text { otstrapped u }\end{array}$ & $\begin{array}{l}\text { he } 99 \text { th anc } \\
998 \text { through } \\
\text { our-digit IS } \\
0 \text { repetition }\end{array}$ & $\begin{array}{l}\text { he balanced } \\
\text { and in }\end{array}$ \\
\hline
\end{tabular}


Table 5: Labor Share of Sales and Output Tariffs: Effect of Geographic Remoteness

\begin{tabular}{|c|c|c|c|c|}
\hline & \multicolumn{2}{|c|}{ No Control for Markup } & \multicolumn{2}{|c|}{ Controlling for Markup } \\
\hline & (1) & (2) & (3) & (4) \\
\hline Lag Output Tariff & $\begin{array}{l}-3.790 * \\
(1.927)\end{array}$ & $\begin{array}{c}-4.830 * * \\
(1.929)\end{array}$ & $\begin{array}{c}-5.866^{* *} \\
(2.351)\end{array}$ & $\begin{array}{c}-5.306 * * \\
(2.752)\end{array}$ \\
\hline Lag Output Tariff x Remoteness & $\begin{array}{c}4.831 * * \\
(2.131)\end{array}$ & $\begin{array}{c}5.284 * * \\
(2.112)\end{array}$ & $\begin{array}{c}5.618 * * \\
(2.211)\end{array}$ & $\begin{array}{c}5.343 * * \\
(2.395)\end{array}$ \\
\hline Lag Markup & & & $\begin{array}{c}0.209 * * \\
(0.069)\end{array}$ & $\begin{array}{c}0.213 * * \\
(0.070)\end{array}$ \\
\hline Constant & $\begin{array}{c}9.242 * * * \\
(0.150)\end{array}$ & $\begin{array}{c}9.225 * * * \\
(0.241)\end{array}$ & $\begin{array}{c}9.075^{* * *} * \\
(0.475)\end{array}$ & $\begin{array}{c}8.716^{* * * *} \\
(0.523)\end{array}$ \\
\hline Observations & $1,765,550$ & $1,765,550$ & $1,309,056$ & $1,309,056$ \\
\hline Adjusted $R^{2}$ & 0.62 & 0.62 & 0.65 & 0.65 \\
\hline Firm FE & $\mathrm{Y}$ & $\mathrm{Y}$ & Y & $\mathrm{Y}$ \\
\hline Year FE & - & $\mathrm{Y}$ & - & $\mathrm{Y}$ \\
\hline
\end{tabular}


Table 6. Labor Share of Value Added and the Effective Rate of Protection

\begin{tabular}{|c|c|c|c|c|}
\hline & \multicolumn{2}{|c|}{ No Control for Markup } & \multicolumn{2}{|c|}{ Controlling for Markup } \\
\hline & (1) & (2) & (3) & (4) \\
\hline & Wage Bill/VA & Wage Bill/VA & Wage Bill/VA & Wage Bill/VA \\
\hline Lag IERP & $\begin{array}{c}-1.522 * \\
(0.838)\end{array}$ & $\begin{array}{c}-2.279 * * \\
(0.922)\end{array}$ & $\begin{array}{c}-2.618 * * \\
(1.085)\end{array}$ & $\begin{array}{c}-2.619 * * \\
(1.142)\end{array}$ \\
\hline Lag IERP x Remoteness & $\begin{array}{c}2.279 * * \\
(0.954)\end{array}$ & $\begin{array}{c}2.729 * * * \\
(1.001)\end{array}$ & $\begin{array}{c}3.182 * * * \\
(1.178)\end{array}$ & $\begin{array}{c}3.148 * * * \\
(1.062)\end{array}$ \\
\hline Lag Markup & & & $\begin{array}{c}0.370 * * \\
(0.140)\end{array}$ & $\begin{array}{c}0.372 * * \\
(0.145)\end{array}$ \\
\hline Constant & $\begin{array}{c}28.31 * * * \\
(0.105)\end{array}$ & $\begin{array}{c}28.80 * * * \\
(0.435)\end{array}$ & $\begin{array}{c}27.71 * * * \\
(0.947)\end{array}$ & $\begin{array}{c}27.54 * * * \\
(0.807)\end{array}$ \\
\hline Observations & $1,628,397$ & $1,628,397$ & $1,151,123$ & $1,151,123$ \\
\hline Adjusted $R^{2}$ & 0.54 & 0.54 & 0.58 & 0.58 \\
\hline Firm FE & $\mathrm{Y}$ & $\mathrm{Y}$ & $\mathrm{Y}$ & $\mathrm{Y}$ \\
\hline Year FE & - & $\mathrm{Y}$ & - & $\mathrm{Y}$ \\
\hline
\end{tabular}


Table 7: Labor Share of Sales and Output Tariffs: Differences by Ownership

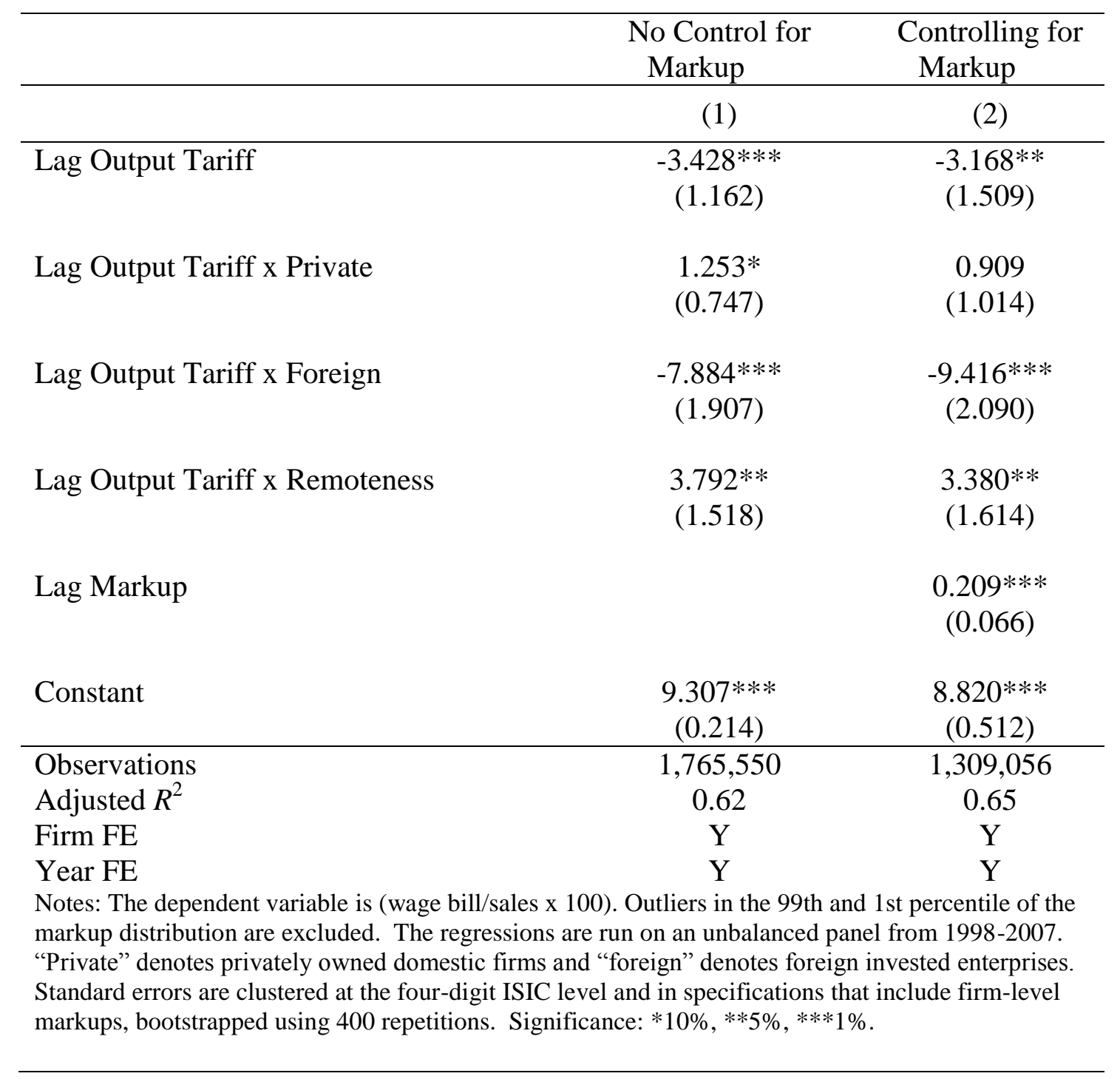


Table 8. Labor Share of Sales and Output Tariffs: Effects of Union Presence

\begin{tabular}{|c|c|c|c|c|c|c|}
\hline & \multicolumn{2}{|c|}{ All Enterprises } & \multicolumn{2}{|c|}{ Private Enterprises } & \multicolumn{2}{|c|}{ Foreign Invested Enterprises } \\
\hline & (1) & (2) & (3) & (4) & $(5)$ & (6) \\
\hline Lag Output Tariff & $\begin{array}{l}-2.982 * * \\
(1.388)\end{array}$ & $\begin{array}{l}-4.521 * \\
(2.593)\end{array}$ & $\begin{array}{c}-1.356 * * \\
(0.670)\end{array}$ & $\begin{array}{c}-2.491 \\
(1.1621)\end{array}$ & $\begin{array}{l}-3.604 * \\
(1.953)\end{array}$ & $\begin{array}{l}-5.272 * * \\
(2.640)\end{array}$ \\
\hline \multirow{2}{*}{$\begin{array}{l}\text { Lag Output Tariff } x \\
\text { Union }\end{array}$} & $1.110^{*}$ & $2.843 * *$ & 0.906 & $1.999 *$ & 1.208 & $3.886^{* * *}$ \\
\hline & $(0.654)$ & $(1.361)$ & $(0.635)$ & $(1.187)$ & $(0.875)$ & $(1.254)$ \\
\hline Lag Markup & & $\begin{array}{c}0.170 * * \\
(0.082)\end{array}$ & & $\begin{array}{l}-0.003 \\
(0.059)\end{array}$ & & $\begin{array}{c}0.370 * * \\
(0.147)\end{array}$ \\
\hline Lag Markup x Union & & $\begin{array}{c}0.134 \\
(0.091)\end{array}$ & & $\begin{array}{l}0.242 * \\
(0.139)\end{array}$ & & $\begin{array}{c}0.119 \\
(0.159)\end{array}$ \\
\hline Constant & $\begin{array}{c}9.217 * * * \\
(0.234)\end{array}$ & $\begin{array}{c}8.555 * * * \\
(0.465)\end{array}$ & $\begin{array}{c}7.823 * * * \\
(0.167)\end{array}$ & $\begin{array}{c}7.194 * * * \\
(0 . .87)\end{array}$ & $\begin{array}{c}9.857 * * * \\
(0.267)\end{array}$ & $\begin{array}{c}8.837 * * * \\
(0.679)\end{array}$ \\
\hline Observations & $1,208,830$ & 970,105 & 640,091 & 507,381 & 295,687 & 242,625 \\
\hline Adjusted $R^{2}$ & 0.61 & 0.65 & 0.57 & 0.62 & 0.63 & 0.67 \\
\hline Firm FE & $\mathrm{Y}$ & $\mathrm{Y}$ & $\mathrm{Y}$ & $\mathrm{Y}$ & $\mathrm{Y}$ & $\mathrm{Y}$ \\
\hline Year FE & $\mathrm{Y}$ & $\mathrm{Y}$ & Y & $\mathrm{Y}$ & Y & $\mathrm{Y}$ \\
\hline \multicolumn{7}{|c|}{$\begin{array}{l}\text { Notes: The dependent variable is (wage bill/sales x 100). Outliers in the 99th and 1st percentile of the markup } \\
\text { The regressions are run on an unbalanced panel from 1998-2007 and only include firms present in } 2004 \text {. } \\
\text { Standard errors are clustered at the four-digit ISIC level and in specifications that include firm-level markups, } \\
\text { bootstrapped using } 400 \text { repetitions. Significance: } * 10 \%, * * 5 \%, * * * 1 \% \text {. }\end{array}$} \\
\hline
\end{tabular}


Table 9. Labor Share of Sales and Output Tariffs, Five-Year Difference Regressions

\begin{tabular}{|c|c|c|c|c|}
\hline & \multicolumn{2}{|c|}{ No Control for Markup } & \multicolumn{2}{|c|}{ Controlling for Markup } \\
\hline & (1) & $(2)$ & (3) & (4) \\
\hline Change in Lag Output Tariff & $\begin{array}{c}-5.169 * * \\
(2.041)\end{array}$ & $\begin{array}{c}-7.447 * * * \\
(2.540)\end{array}$ & $\begin{array}{c}-4.900 * * \\
(2.154)\end{array}$ & $\begin{array}{c}-7.419 * * * \\
(2.525)\end{array}$ \\
\hline Change in (Lag Output Tariff $x$ Remoteness) & & $\begin{array}{c}5.011 * * * \\
(1.652)\end{array}$ & & $\begin{array}{c}5.585 * * * \\
(1.597)\end{array}$ \\
\hline -(Change in Log Material Share) & & & $\begin{array}{c}1.449 * * * \\
(0.275)\end{array}$ & $\begin{array}{c}1.456^{* * * *} \\
(0.269)\end{array}$ \\
\hline Observations & 283,341 & 280,637 & 270,249 & 267,644 \\
\hline
\end{tabular}

The dependent variable is the five-year change in (wage bill/sales x 100). Standard errors are clustered at the four-digit ISIC level and in specifications that include firm-level markups, bootstrapped using 400 repetitions.

Significance: $* 10 \%, * * 5 \%, * * * 1 \%$. 
Table 10: Labor Share of Sales and Output Tariffs, Five-Year Difference Regressions with Controls for Initial Tariffs

\begin{tabular}{|c|c|c|c|c|}
\hline & \multicolumn{2}{|c|}{ No Control for Markup } & \multicolumn{2}{|c|}{ Controlling for Markup } \\
\hline Change in Lag Output Tariff & $\begin{array}{c}-4.760 * * \\
(1.838)\end{array}$ & $\begin{array}{c}-7.062 * * * \\
(2.031)\end{array}$ & $\begin{array}{c}-4.764 * * \\
(2.139)\end{array}$ & $\begin{array}{c}-7.256 * * * \\
(2.227)\end{array}$ \\
\hline Change in (Lag Output Tariff x Remoteness) & & $\begin{array}{c}5.012 * * * \\
(1.652)\end{array}$ & & $\begin{array}{c}5.586 * * * \\
(1.604)\end{array}$ \\
\hline Initial Output Tariff & $\begin{array}{c}0.305 \\
(1.692)\end{array}$ & $\begin{array}{c}0.288 \\
(1.617)\end{array}$ & $\begin{array}{c}0.102 \\
(1.891)\end{array}$ & $\begin{array}{c}0.122 \\
(1.978)\end{array}$ \\
\hline Observations & 283,341 & 280,637 & 270,249 & 267,644 \\
\hline
\end{tabular}

Notes: The dependent variable is the five-year change in (wage/sales x 100). Standard errors are clustered at the four-digit ISIC level and in specifications that include firm-level markups, bootstrapped using 400 repetitions. Significance: *10\%, **5\%, ** 
Figure 1: Trends in Average Tariffs, 1998-2007

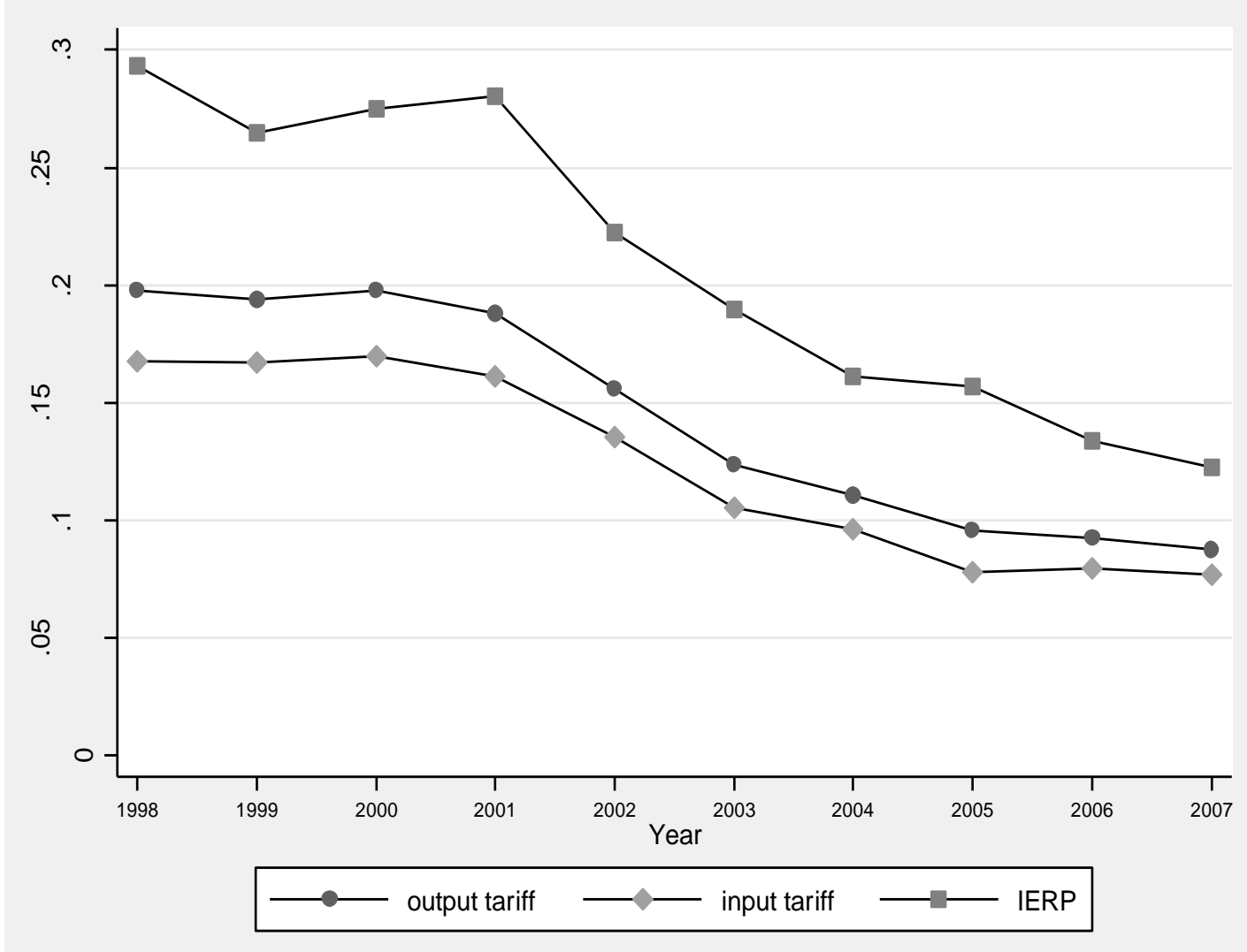

Notes: Output tariff is the effectively applied tariff weighted by imports at the four-digit ISIC Rev. 3 level. Input tariff is a weighted average of the output tariffs at the five-digit IO sector level where weights are obtained from the 2002 Chinese input-output matrix. IERP is the industry effective rate of protection. All tariff measures defined in Table 1 
Figure 2: Ratio of Average High-Tariff-Cut-Industry Labor Share of Sales to Mean Low-Tariff-Cut-Industry Labor Share of Sales, 1998-2007

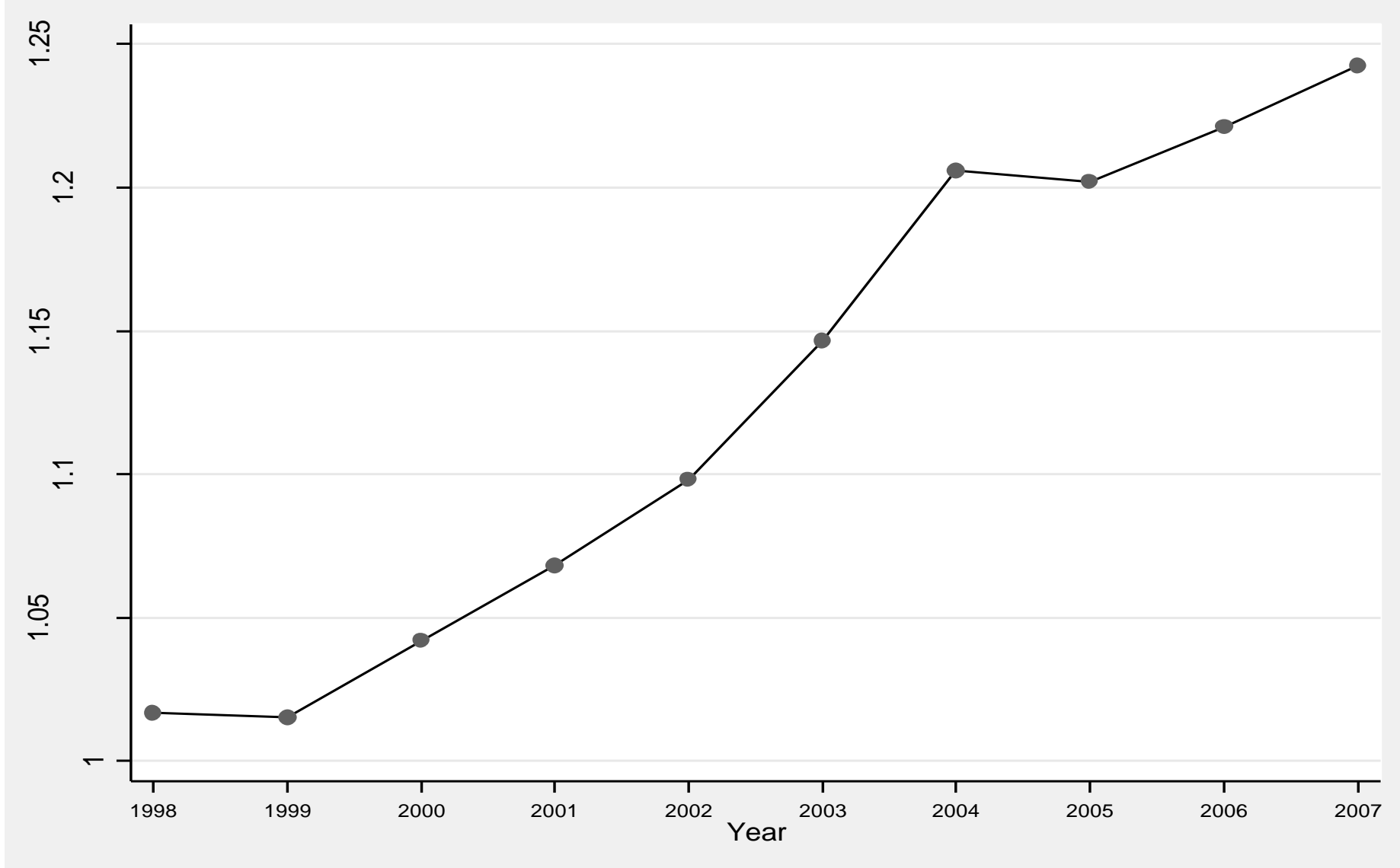

Note: High-tariff cut industries are those with tariff cuts exceeding the average for all industries over the period. Low-tariff cut industries are all others. 
Figure 3: Estimated Average Markup, 1998-2007

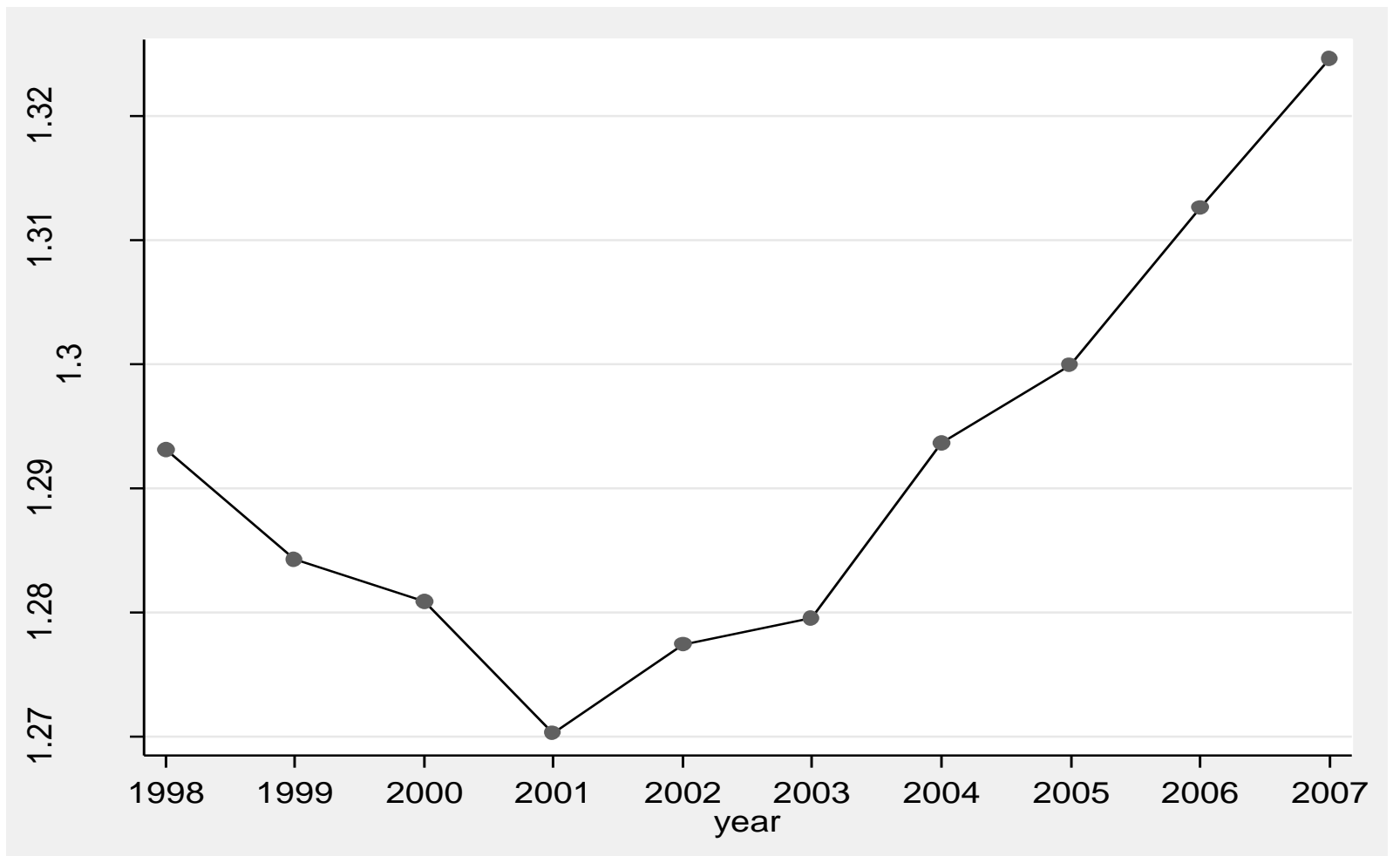

Notes: Markups estimated using the De Loecker, Goldberg, Khandelwal, and Pavcnik (2012) method and an unbalanced panel from the ASIP. See text for details. 